\title{
KARAKTER FISIK KOTA CAKRANEGARA
}

\author{
Lalu Mulyadi 1) dan Agung Murti Nugroho*2) \\ 1) Jurusan Arsitektur Fakultas Teknik, ITN Malang \\ 2) Jurusan Arsitektur Fakultas Teknik, Universitas Brawijaya Malang \\ *email : sasimurti@yahoo.co.id
}

\begin{abstract}
ABSTRAK
Tujuan utama konservasi kota lama di Indonesia adalah pemenuhan kebutuhan saat ini tanpa membuang karakter khusus yang perlu dipertahankan untuk warisan dan identitas kota. Kawasan Cakranegara di Lombok yang dahulu merupakan kota lama dengan pola gridnya merupakan kota yang perlu diketahui karakter khusus secara fisik serta konsep tata ruangnya. Makalah ini mencoba mengkaji konsep tata ruang kota Cakranegara terutama pada karakter fisiknya Metode yang digunakan untuk mengidentifikasikan karakter fisik dengan pengamatan visual. Hasil kajian menunjukkan bahwa pola grid dan kedudukan pura adalah karakter yang menonjol. Kajian ini menyimpulkan bahwa prinsip tata ruang fisik dibentuk oleh konsep tata ruang rumah dan pemukiman.
\end{abstract}

Keywords - karakter fisik, kawasan Cakranegara

\section{PENDAHULUAN}

Kajian tentang karakter dan konsep tata ruang yang menunjukkan identitas yang khas dari suatu kawasan belum banyak dilakukan di Indonesia. Pola jalan, pola tata ruang dan bangunan pada kawasan kota bersejarah seperti kasus kota lama Cakarnegara di Lombok mengungkapkan dua hal yang harus diidentifikasi yaitu karakter dan konsep. Kuda hal tersebut cenderung mengalami perubahan baik oleh pihak pemerintah daerah maupun masyarakat. Oleh karena itu kajian tentang karakter fisik perlu dilakukan untuk identifikasi awal elemen kawasan maupun rumah sebagai rujukan untuk konservasi kawasan. Karakter sebuah kota adalah prinsip yang mempengaruhi identitas maupun citra sebuah kota. Karakter fisik seperti bentuk dan tata ruang kota dapat membentuk presepsi visual terhadap lingkungan kota (Sanoff, 1991). Oleh karena itu karakter fisik memainkan peranan penting dalam menghasilkan sebuah citra kota yang sesuai dan menarik. Dalam konteks perkembangan kota, kajian karakter fisik adalah penting untuk menentukan hubungan yang seimbang antara unsur lama dengan unsur baru. Dengan demikian kajian karakter lingkungan kota perlu dilakukan terlebih dahulu sebelum menentukan konsep tata ruang kota. Cakranegara sebagai sebuah lingkungan kota lama dan bersejarah yang berlokasi di pulau Lombok, Indonesia merupakan kawasan yang memiliki tata ruang yang khusus. Menurut Funo (1995) Cakranegara adalah sebuah kota berpola grid yang dibentuk oleh blok-blok kawasan perumahan. Handinoto (2000) menyatakan bahwa Cakranegara adalah salah satu kota tua di Indonesia yang dirancang berdasarkan falsafah Hindu. Selanjutnya Suardana (2005) menyatakan bahwa Cakranegara adalah kota seribu perempatan. Oleh sebab itu maka kajian tentang karakter fisik kawasan Cakranegara penting dilakukan. 


\section{METODE PENELITIAN}

Penelitian ini menggunaan metode pengamatan visual yang digunakan untuk mengidentifikasi bentuk fisik kota. Hasil kajian ini akan digunakan untuk perbandingan dan juga memperlengkap informasi penelitian sebelumnya.

Menurut Worskett (1969) karakter fisik kota dapat dianalisis dengan menilai pandangan secara subjektif dan memeriksa bukti-bukti arkeologi yang mempengaruhinya sehingga metode pengamatan visual merupakan salah satu tahapan yang penting dalam penelitian lingkungan kota. Menurut Spreiregen (1965) kekuatan utama teknik pengamatan visual ialah memungkinkan peneliti mengkaji bentuk, komposisi dan rupa kota. Menurut Shuhana dan Ahmad Bashri (1992) penggunaan teknik pengamatan visual dalam penelitian mempunyai kelebihan terutama untuk menerangkan bentuk dan rupa kota secara jelas dan terperinci.

Menurut Rapoport (1976) metode pengamatan visual dapat digunakan untuk mempelajari pola tata ruang yang berasaskan sosial budaya seperti pada kawasan tradisional. Hal ini juga dibenarkan oleh Wikantiyoso (1999) yang menyatakan bahwa untuk mendapatkan konsep tata ruang kawasan tradisional, penggunaan metode ini lebih akurat karena didapatkan tipologi susunan rumah dan tipologi tata ruang yang ada di dalam sebuah kawasan. Berdasarkan aspek keluasannya pengamatan visual kepada tata ruang kota dapat dikelompokkan menjadi tiga kategori, yaitu tata ruang mikro, mezo dan makro (Haryadi, 1995). Lingkup mikro adalah lingkungan rumah, mezo adalah kawasan pemukiman sedangkan makro adalah kawasan kota secara keseluruhan. Metode pengamatan visual terbagi atas tiga cara, yaitu pengamatan, pemeriksaan dan pengukuran. Shuhana dan Ahmad Bashri (2002) menyatakan bahwa pengamatan karakter fisik kawasan secara terperinci dapat diperoleh melalui kajian pengamatan visual dan penggambaran terukur elemenelemen fisiknya.

\section{HASIL DAN PEMBAHASAN}

Kajian pangamatan visual kajian ini dibagi dalam tiga tahap yaitu tahap pertama lingkup kawasan kota secara keseluruhan seperti batas kawasan, kedudukan bangunan-bangunan penting, bentuk struktur jalan, bentuk ruang terbuka serta kegunaannya Tahap kedua lingkup kawasan pemukiman seperti batas pemukiman, bangunan-bangunan penting, bentuk dan jenis jalan, ruang terbuka, serta kegunaannya. Tahap ketiga lingkup lingkungan rumah seperti pada gambar 4. Kawasan kota secara keseluruhan diambil satu sampel yaitu kawasan Cakranegara, kawasan pemukiman diambil tujuh sampel, dan lingkungan rumah diambil duapuluh satu sampel.

Dalam kajian ini teknik pengamatan digunakan untuk merekam elemen-elemen fisik kawasan kajian yang meliputi pengambilan gambar, sketsa dan mencatat informasi penting seperti yang telah dilakukan oleh Spreiregen (1965). Analisis secara deskriptif akan dibuat melalui tiga bagian, yaitu analisis kawasan 
bandar secara keseluruhan, analisis lingkungan pemukiman dan analisis lingkungan rumah. Analisis seperti ini seperti yang dilakukan oleh Shuhana dan Ahmad Bashri (2002).

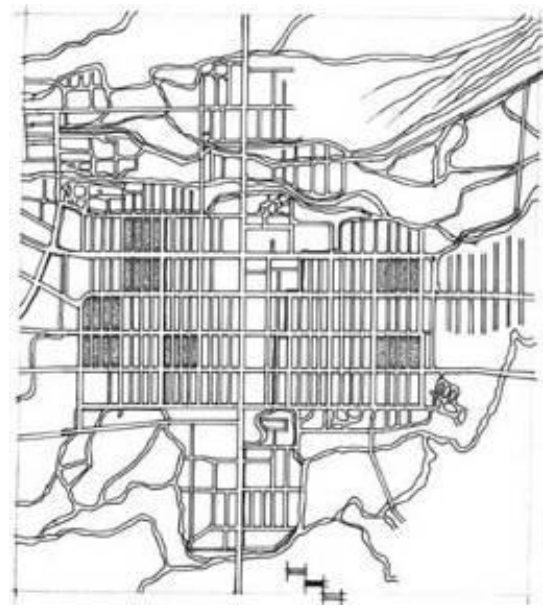

Gambar 1. Tahap 1: Pengamatan skala lingkungan kota

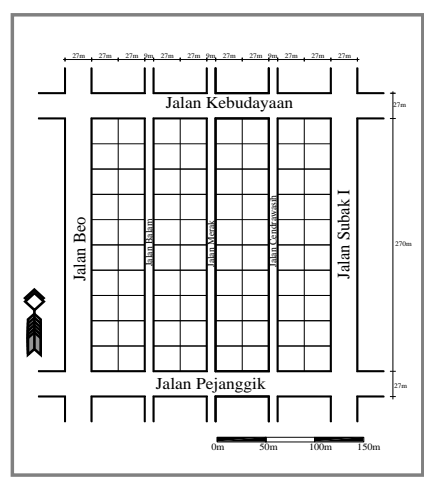

Gambar 2. Tahap 2: Pengamatan skala kawasan pemukiman

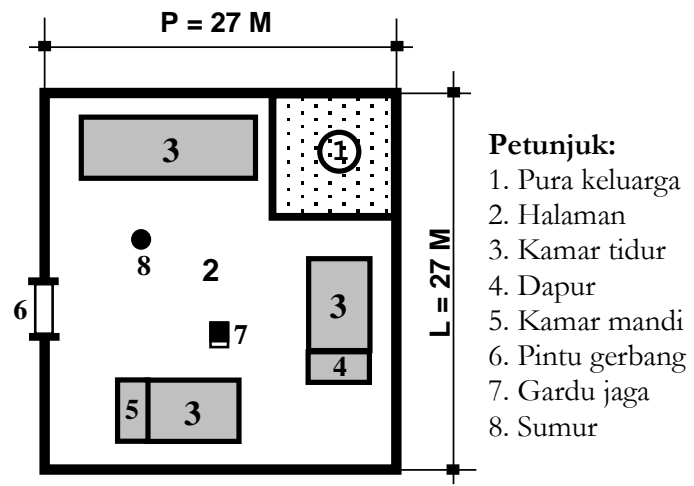

Gambar 3. Tahap 3: Pengamatan skala lingkungan

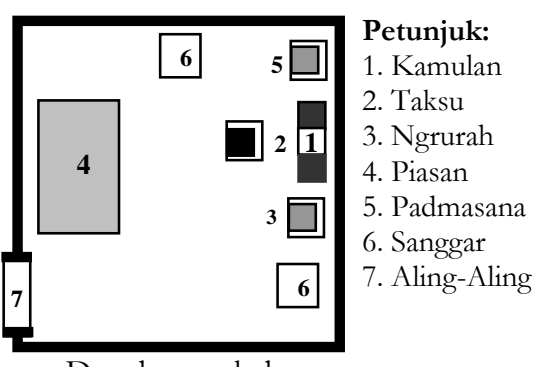

Denah pura keluarga

Gambar 4. Tahap Pengamatan Visual (Sumber: Kaïan Labangan. 2006)

\section{Karakter Fisik Cakranegara}

Hasil kajian karakter fisik pada makalah ini dibagi menjadi dua bagian besar yaitu karakter fisik rumah dan kawasan pemukiman yang masing-masing terbagi atas beberapa pembahasan antara lain pola tata ruang, bentuk dan karakter visual serta hirarki dan orientasi ruang. 


\section{Pola Tata Ruang Rumah}

Tata ruang ruang dan masa dalam lingkungan rumah disusun secara terpisah dengan halaman berada di tengah-tengah setiap lingkungan rumah. Pola tata ruang dan masa rumah secara terpisah memiliki kejelasan fungsi, kejelasan hubungan antar ruang, dan kejelasan orientasi yang merupakan elemen pembentuk karakter fisik lingkungan rumah (gambar 5).

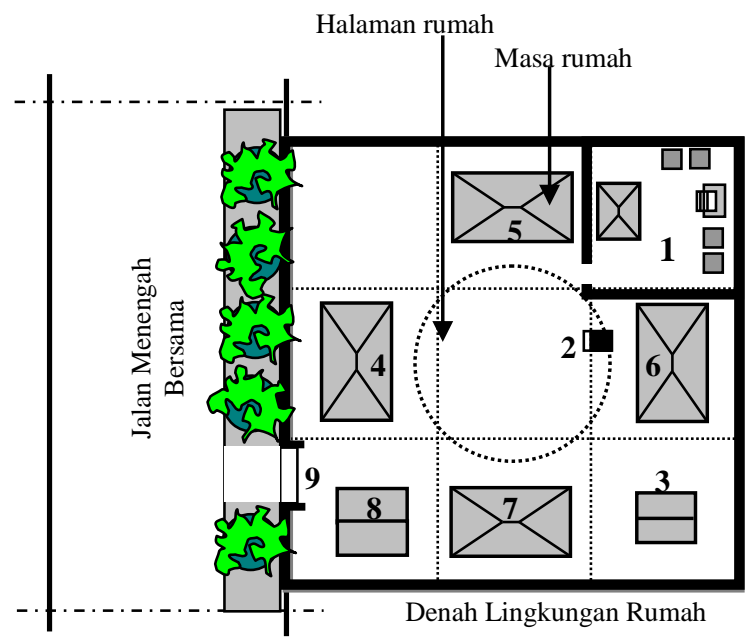

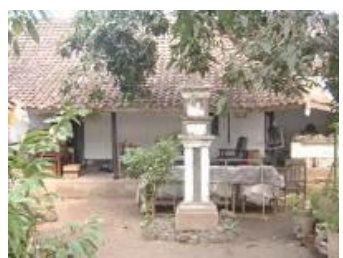

5. Kamar tidur orangtua

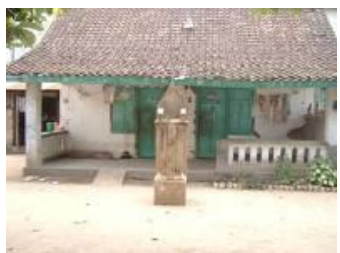

6. Kamar tidur anak lelaki

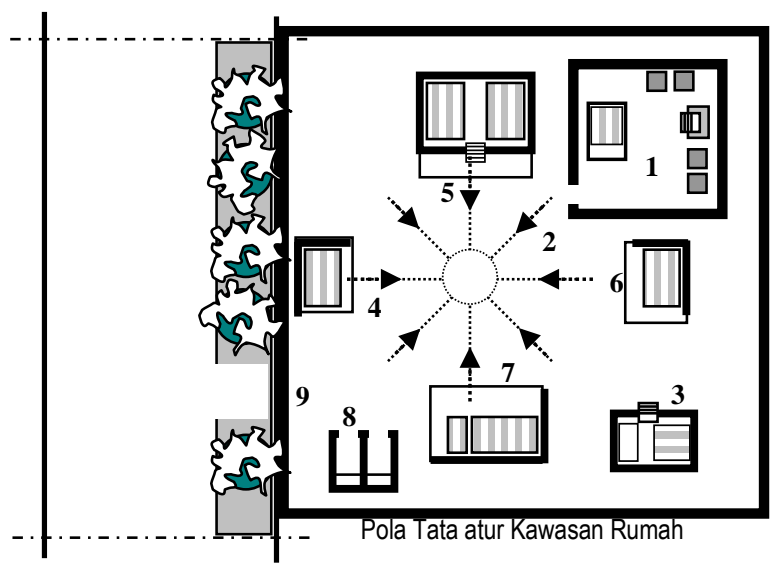

Petunjuk:

1. Pura keluarga

2. Gardu Jaga

3. Dapur

4. Kamar tidur anak perempuan

5. Kamar tidur orangtua

6. Kamar tidur anak lelaki

7. Kamar tidur anak

yang sudah menikah

8. Kamar mandi

9. Pintu gerbang

Gambar 5. Pola Tata Ruang Lingkungan Rumah (Sumber: Kajian Lapangan, 2006)

\section{Bentuk dan Karakter Visual Lingkungan Rumah}

Bentuk kawasan rumah adalah segi empat sama sisi. Bentuk seperti ini dibangun sejak awal pembangunan kawasan kota Cakranegara. Bentuk kawasan rumah yang persegi empat dengan pagar tembok dan pintu gerbang serta ukuran, ketinggian, warna dan hiasan 
yang tersendiri ikut membentuk karakter fisik lingkungan rumah. Batas merupakan elemen linier yang mengatur elemen-elemen untuk memperkuat ikatan lingkungan yang meliputi keseluruhan batas. Menurut Lynch (1960) batas yang paling kuat tidak hanya mempunyai penampilan visual yang baik dan tidak dapat ditembus, kejelasan wujud fisik, fungsi batas, bahan dan perbedaan yang jelas. Pagar bertembok dengan bentuk fisik yang unik yang berfungsi sebagai batas antara lingkungan rumah telah menyumbang kepada pembentukan karakter fisik.
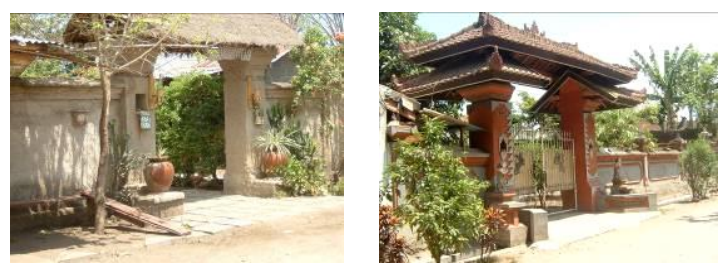

Gambar. 6 Bentuk Pagar Bertembok dan Pintu Gerbang

\section{Hierarki dan Orientasi Tata Ruang Kawasan Rumah}

Menurut Ching (1984) hirarki adalah tingkatan suasana atau nilai ruang yang berbeda. Pengamatan terhadap lingkunan rumah menghasilkan formasi tata ruang terpisah dan memiliki fungsi dan kedudukan yang khusus. Perbedaan fungsi, nilai ruang, dan suasana membentuk hirarki. Hirarki ini dapat menyumbang kepada pembentukan karakter fisik kawasan rumah. Lingkungan rumah memiliki orientasi yang dibentuk oleh perbedaan karakter fisik dan perbedaan fungsi masa bangunan. Tata ruang lingkungan rumah berorientasi ke arah Gunung Rinjani. Kedudukan pura yang sama di setiap lingkungan rumah membentuk karakter fisik lingkungan rumah.

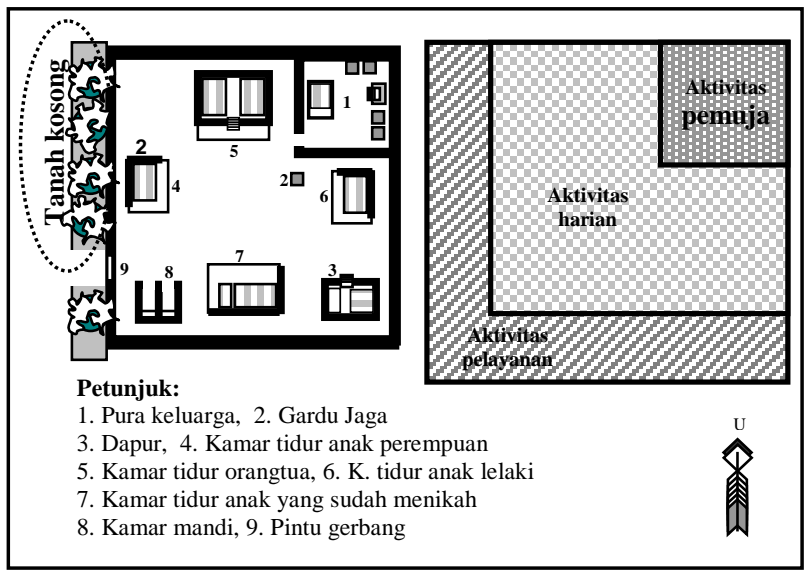

Gambar 7. Hirarki Tata Ruang Lingkungan Rumah (Sumber: Kaïan, 2007) 


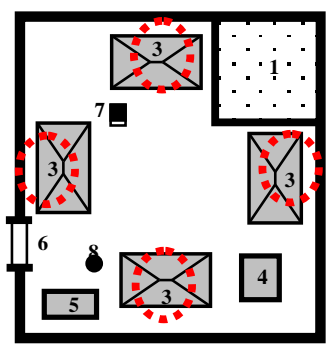

Interpretasi:

1. Mengikut kedudukan kamar tidur

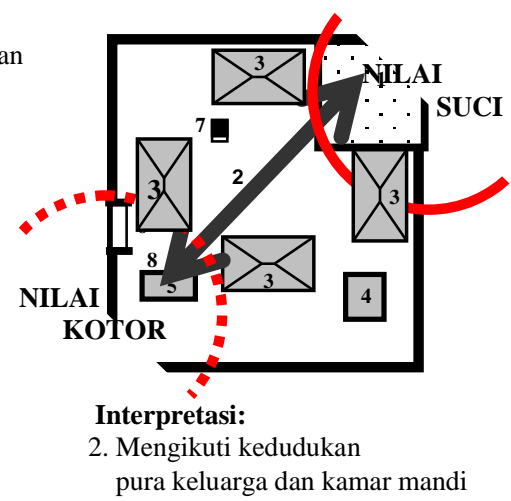

Petunjuk:

1. Pura keluarga, 2. Halaman rumah, 3. Kamar tidur orangtua dan anak, 4. Dapur, 5. Kamar Mandi, 6. Pintu gerbang, 7. Pos jaga, 8.

Gambar 8. Orientasi Tata Ruang Kawasan Rumah

\section{Pola Tata Ruang Lingkungan Pemukiman}

Berdasarkan pengamatan pada tujuh sampel kawasan pemukiman ditemukan pola jalan menghadap ke utaraselatan dan blok-blok kawasan pemukiman tersusun berderet utara-selatan seperti yang ditunjukkan dalam gambar 9. Pola tata ruang dan blok kawasan pemukiman ini menjadi komponen penting dalam karakter fisik kawasan.

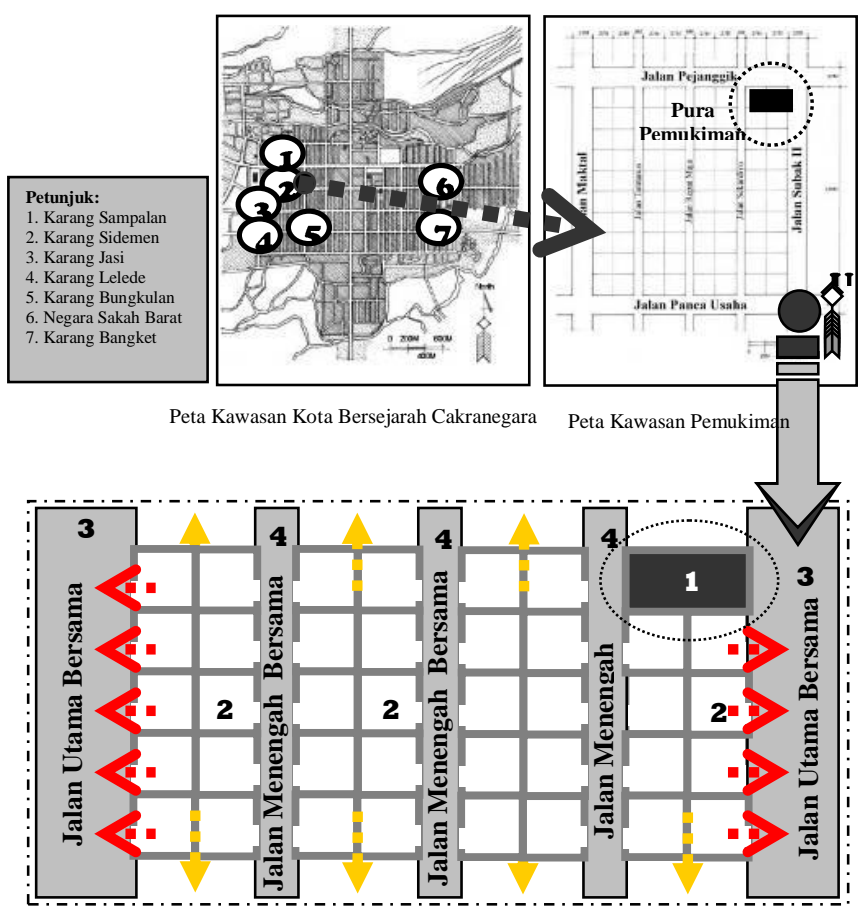

Gambar 9. Formasi Tata Ruang Kawasan Pemukiman (Sumber: Kaïan Lapangan, 2006)

\section{Bentuk dan Karakter Visual Ruang Kawasan Pemukiman}

Kajian mendapati bentuk blok pemukiman berdasarkan kepentingan makna diambil daripada sistem komunitas masyarakat Hindu yang bertahan hingga hari ini. Ini sesuai dengan pernyataan Shuhana (1997) bahwa pembentukan identitas suatu tempat dipengaruhi oleh keistimewaan karakternya. Pada aspek 
kajian visual, dua elemen yang menonjol adalah fungsi, tipe jalan dan tanah kosong di hadapan rumah dan yang kedua adalah pura pemukiman. Jalan berfungsi sebagai ruang terbuka dan sebagai tempat untuk menjalankan aktivitas sosial budaya dan keagamaan sementara tanah kosong diperuntukkan untuk menanam pohon dan tempat upacara adat-istiadat keagamaan. Pura pemukiman berfungsi sebagai tempat pemujaan dan mempunyai ciri-ciri unik seperti pembatas pagar tembok dan adanya bale kulkul. Bentuk bale kulkul dapat memberikan citra kepada kawasan pemukiman. Ini sesuai dengan penyataan Gelebet (1986) bahwa pura adalah bagian utama bagi kawasan karena mampu menghidupkan kawasan tersebut. Sehingga secaa ringkas elemen jalan yang berfungsi sebagai ruang bersama dan aktivitas sosial budaya, tanah kosong untuk penanaman pohon dan upacara keagamaan, serta pura sebagai tempat pemujaan merupakan elemen fisik yang dapat menyumbang kepada karakter fisik kawasan pemukiman.

\section{Hierarki dan Orientasi Tata Ruang Kawasan Pemukiman}

Formasi tata masa kawasan pemukiman dan penempatan pura pemujaan serta batas kawasan yang jelas dapat membentuk hirarki ruang. Menurut Gelebet (1986) dan Dharmayudha (1999) tiga unsur yang menyebabkan kawasan pemukiman memiliki hirarki, yaitu jiwa, tenaga dan badan. Lebih jauh dijelaskan bahwa pura adalah jiwa, rumah tempat tinggal adalah tenaga dan batas adalah badan. Ardi (1986) menyatakan untuk mengetahui hirarki kawasan masyarakat Hindu Bali adalah melalui pengamatan terhadap kedudukan pura, kawasan rumah dan bataskawasan. Suwena (2003) menyatakan penilaian hirarki bagi masyarakat Bali boleh dilihat pada topografi (tinggi-datar-rendah) dan kedudukan pura, tempat tinggal dan jalan. Secara ringkas kawasan pemukiman Cakranegara memiliki hirarki yang diwujudkan oleh formasi dan fungsi tata ruang yang berbeda. Hirarki yang dibentuk oleh formasi susunan pura pemukiman, blok kawasan rumah dan batas adalah elemen yang dapat menyumbang kepada pembentukan karekter fisik kawasan tersebut.

Menurut Ardi (1986), Gelebet (1986), Budihardjo (1991), Geriya (2004) dan Eiseman (2005), penilaian terhadap orientasi tata ruang kawasan pemukiman masyarakat Hindu Bali dapat dilakukan dengan memeriksa formasi tata ruang kawasan yang bernilai berlawanan, seperti kedudukan tempat ibadah paling tinggi berbanding kedudukan perkuburan. Pengamatan kondisi lapangan menemukan bahwa orientasi tata ruang kawasan pemukiman menghadap ke arah timur laut. Elemen orientasi seperti ini dapat menyumbang kepada pembentukan karakter fisik kawasan pemukiman di kawasan kota Cakranegara. 


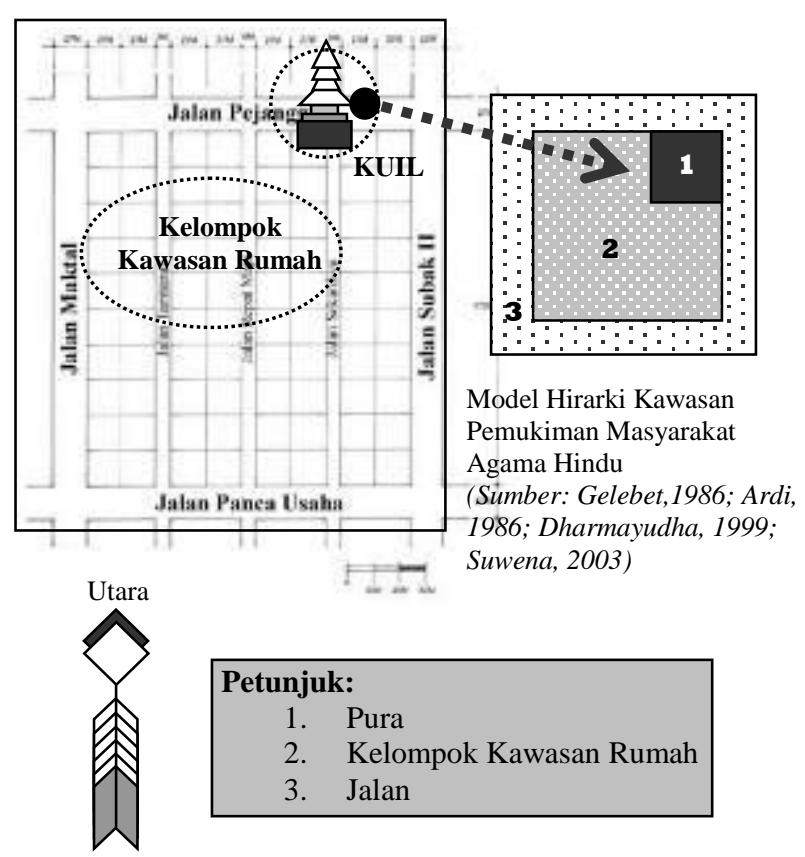

Gambar 10. Pola Tata Ruang Pura di Kawasan Pemukiman

\section{KESIMPULAN}

Karakter fisik adalah kualitas visual yang dihasilkan dari gabungan berbagai elemen kota Cakranegara. Perbedaan karakter antar kota-kota di Indonesia disebabkan oleh perbedaan kombinasi elemen dan kualitas dan berhubungan erat dengan identitas dan citra kota. Kualitas yang dominan akan menghasilkan karakter yang kuat yang amat mempengaruhi persepsi dan kognisi masyarakat setempat.

Secara ringkas karakter fisik rumah meliputi pembagian ruang, bentuk dan pintu gerbang. Pembagian ruang terlihat dengan posisi ruang misalnya bagian utara adalah ruang orangtua, bagian timur ruang anak lelaki, bagian selatan ruang anak yang sudah berkahwin, bagian barat ruang anak perempuan, bagian timur laut pura keluarga, bagian tenggara dapur, bagian barat daya kamar mandi, bagian barat laut gardu jaga dan di tengah-tengah kawasan adalah halaman rumah. Bentuk kawasan rumah yang segi empat dengan pagar bertembok yang berfungsi sebagai batas dan mempertegas bentuk kawasan tersebut. Ukuran dan ketinggian pagar tembok (1.80 meter) dapat berfungsi melindungi dan menjaga keamanan penghuni. Di setiap kawasan rumah terdapat pintu gerbang yang berfungsi sebagai pintu masuk ke kawasan rumah.

Karakter fisik kawasan pemukiman terdiri atas deretan kawasan rumah menghadap utara-selatan, posisi pura pemukiman, pola jalan serta keteraturan arah pintu gerbang rumah menghadap ke arah timur dan barat. Pola tata ruang kawasan pemukiman yang diambil dari sistem komunitas adalah banjar. Banjar merupakan sebuah pola tata ruang yang baik karena memberikan identitas kawasan berupa batas kawasan yang jelas dan adanya tempat ibadah.

Secara umum kajian ini menemukan terdapat beberapa elemen yang penting yang membentuk karakter kota. Kualiti yang penting bagi bandar Cakranegara ialah 
makna, aktivitas dan fisik. Kualitas makna disumbangkan oleh kebiasaaan dan nilai sejarah. Kebiasaan mempunyai kaitan dengan tahap penggunaan kawasan kota. Kualitas aktivitas disumbangkan oleh kekerapan aktivitas sosial budaya dan keagamaan yang dilakukan di dalam kawasan kota. Kualitas fisik disumbang oleh rupa bentuk struktur ruang kawasan dan bangunan-bangunan penting. Rupa bentuk struktur ruang dan bangunan penting mempunyai kaitan dengan persepsi masyarakat setempat. Dalam kajian ini elemen-elemen utama yang mempunyai kaitan dengan kebiasaan dan kekerapan aktivitas adalah pura di pemukiman, tiga pura utama kawasan, simpang empat di tengah kota maupun di setiap blok kawasan, dan jalan dengan ukuran besar (45.00 meter), sedang (27.00 meter), dan kecil (09.00 meter). Sementara elemen yang mempunyai kaitan dengan rupa bentuk ialah struktur jalan berbentuk simpang empat yang banyak (pola grid) dan bangunan pura Meru.

\section{REFERENSI}

Funo, Shuji (1995). Cakranegara, A Unique Hindu City in Lombok (Indonesia) The Grid in the Tradition of Asian City Planning. Surabaya: Makalah yang disampaikan dalam Seminar Arsitektur Nusantara, Keajekan dan Perubahan, World Trade Centre.

Handinoto (2000). Sistem Jalan di Cakranegara dan Purbolinggo, Sebuah Perbandingan. Jurnal Dimensi. Surabaya: Petra Press.

Sanoff H. (1991). Visual Research Method in Design. New York: Van Nostrand Reinhold.
Suardana, I.N.G. (2005). Arsitektur Bertutur. Denpasar: Yayasan Pustaka Bali.

Shuhana Shamsuddin \& Ahmad Bashri Sulaiman (2002). Developing A Guideline for Designing Urban Intervention in Places of Historical and Cultural Significance in Malaysia. Unpublished Research Report. Skudai, Johor Bahru: Jabatan Seni Bina, Fakulti Alam Bina. Universiti Teknologi Malaysia. Spreiregen Paul D. (1965). Urban Design. The Architecture of Town and Cities. New York: McGraw-Hill.

Worskett (1969). The Character of Towns. London: Architectural Press. 